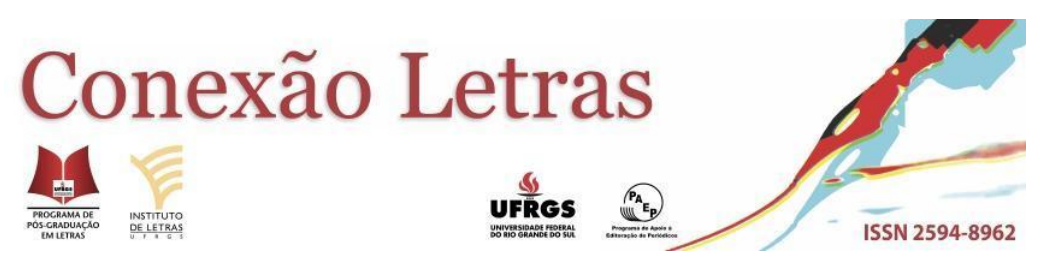

\title{
O SEMANTISMO DO SUBSTANTIVO NA PERSPECTIVA DA TEORIA DAS OPERAÇÕES ENUNCIATIVAS: PRINCÍPIOS DE VARIAÇÃO NO CONFRONTO NOME-VERBO
}

NOUN SEMANTISM FROM A THEORY OF ENUNCIATIVE OPERATIONS PERSPECTIVE: NOUN X VERB VARIATION PRINCIPLES

\author{
Márcia Romero ${ }^{1}$ \\ Leonam Francisconi ${ }^{2}$ \\ Larissa Fujisaka ${ }^{3}$
}

Resumo: O artigo apresenta os resultados preliminares decorrentes da pesquisa Léxico e Enunciação, que, em sua etapa atual, examina as regularidades de ordem enunciativa do substantivo. Para tanto, fundamenta-se em dois dos estudos que a integram e que descrevem o funcionamento dos substantivos CHAVE e FACA em seus empregos. Os estudos, cujo referencial teórico-metodológico é a Teoria das Operações Enunciativas, visam a explicar como o semantismo do substantivo, formalizado por meio de um esquema invariante, contribui para validar a existência de princípios que ordenam o processo de significação e a variação semântica das unidades. Ao confrontar os resultados obtidos àqueles provenientes de estudos sobre as regularidades de ordem enunciativa do verbo, o artigo sustenta a hipótese de ser a variação semântica da unidade linguística regida por princípios da mesma natureza, constitutivos da atividade de linguagem.

Palavras-chave: Variação semântica nominal. Variação semântica verbal. Princípios regulares de variação.

\begin{abstract}
This article presents preliminary results from Lexis \& Enunciation research which, in its current phase, examines noun enunciative regularities. The discussion hereafter is based on two studies that describe the function and uses of the nouns CHAVE (key) and FACA (knife). These studies, underpinned by the Theory of Enunciative Operations, seek to explain how the noun semantism, formed by an invariant scheme, contributes to validating the existence of principles that govern the process of signification and semantic variation of such linguistic units. When comparing these results to those found in studies on the enunciative regularities of verbs, this article supports the hypothesis that the semantic variation of the linguistic unit is governed by the same principles which constitute linguistic activity.
\end{abstract}

Keywords: Noun semantic variation. Verb semantic variation. Variation governing principles.

\section{Introdução}

\footnotetext{
${ }^{1}$ Doutora pela Universidade de São Paulo (USP). Professora da Universidade Federal de São Paulo (UNIFESP). Vinculada ao PPG em Educação e Saúde na Infância e na Adolescência e responsável pelo projeto de pesquisa Léxico e Enunciação. Das regularidades enunciativas do substantivo (FAPESP, processo 2019/22495-8).

${ }^{2}$ Mestre pela Universidade Federal de São Paulo (UNIFESP). Vinculado ao PPG em Educação e Saúde na Infância e na Adolescência e integrante do projeto de pesquisa Léxico e Enunciação. Das regularidades enunciativas do substantivo.

${ }^{3}$ Mestre pela Universidade Federal de São Paulo (UNIFESP). Vinculada ao PPG em Educação e Saúde na Infância e na Adolescência e integrante do projeto de pesquisa Léxico e Enunciação. Das regularidades enunciativas do substantivo.
} 
O propósito desse artigo é o de apresentar os resultados preliminares decorrentes da pesquisa Léxico e Enunciação, que, em sua etapa atual, examina as regularidades de ordem enunciativa do substantivo ${ }^{4}$. Para tanto, apoiamo-nos em dois dos estudos que a integram, os de Fujisaka (2020) e Francisconi (2020), direcionados, respectivamente, à formalização do funcionamento semântico-enunciativo dos substantivos CHAVE e FACA ${ }^{5}$. A pesquisa visa a explicar como o semantismo do substantivo sob a ótica do quadro teórico-metodológico adotado, a saber, a Teoria das Operações Enunciativas (note-se TOE) ${ }^{6}$ (CULIOLI, 1990, 1999a, 1999b, ROMERO, 2019), contribui, de um lado, para descrever um substantivo cuja referência tida por prototípica, em diferentes fontes lexicográficas, é a de uma entidade de $1^{\text {a }}$ ordem, i.e. "indivíduos (pessoas, animais e coisas)" (CAMACHO et al., 2014, p. 23), de outro, para validar a existência de princípios regulares que ordenam o processo de significação e a variação semântica nos usos.

No que se refere à conceitualização de semantismo, sustentamos que, qualquer que seja a natureza da unidade linguística, esta apresenta uma identidade semântica de ordem relacional (FRANCKEL, 2002, DE VOGÜÉ et al., 2011, ROMERO, 2019), como exemplificado na seção subsequente. Em termos metalinguísticos, o semantismo é formalizado por meio de uma expressão relacional que especifica, através de parâmetros variáveis, a operação de linguagem executada a cada vez que a unidade se enuncia, integra um enunciado.

Nessa perspectiva, o sentido atribuído a um substantivo resulta de um conjunto de relações ordenadas que se observam no enunciado, mais precisamente, entre as oriundas do sintagma nominal (note-se SN) constituído pelo substantivo e as oriundas do enunciado no qual o próprio SN se insere. A existência de princípios regulares faz notadamente referência ao caráter produtivo e não aleatório de tais relações.

Vale dizer, ainda, que o que se conhece por sentido do substantivo - ou a sua estabilização semântica em um valor ${ }^{7}$ - evidencia o término de um processo de significação

\footnotetext{
${ }^{4}$ Pesquisa financiada pela Fundação de Amparo à Pesquisa do Estado de São Paulo (FAPESP). O projeto em andamento, intitulado Léxico e enunciação. Das regularidades de ordem enunciativa do substantivo (FAPESP 2019/22495-8), dá continuidade à pesquisa direcionada à reconstituição de formas de regularidades próprias à atividade de linguagem que se encontram no fundamento dos processos de significação de unidades morfolexicais. O projeto Léxico e enunciação. Sistematização do funcionamento verbal (FAPESP 2013/07572-0), etapa que antecede a atual, dedicou-se à formalização da identidade semântica de unidades categorizadas como verbo, preposição e prefixo. Ver, no que se refere a resultados desse projeto, Romero e Trauzzola (2016), Romero (2018a), Romero (2018b), Romero (2019), Romero e Vilela (2020a), Romero e Vilela (2020b), entre outros.

${ }^{5}$ Os principais critérios de seleção do corpus envolvem a subclassificação frequente do substantivo como concreto e contável, a sua não formação por derivação e a variedade de usos por ele apresentada.

${ }^{6}$ Em sua denominação estendida, Teoria das Operações Predicativas e Enunciativas.

${ }^{7}$ Utilizamos valor semântico para nos referir aos sentidos adquiridos pelo substantivo nos enunciados.
}

192 - Conexão Letras, Porto Alegre, v. 16, n. 25, p. 191-220, jan-jun. 2021.

E-ISSN 2594-8962. DOI: https://doi.org/10.22456/2594-8962.116838 
que, como dito, só se dá pela integração do SN no enunciado. Ilustrando, se em "A chave quebrou" é possível fazer referência a um objeto (que aciona uma fechadura), antes em perfeito estado, que não conserva a sua forma inicial ou funcionalidade, não é o SN a chave que, por si só, refere ao objeto. É o conjunto das formas linguísticas constituindo o próprio enunciado que faz com que o SN se veja assim determinado ${ }^{8}$. Por ser o sentido adquirido pelo SN dependente de seu enunciar, a caracterização do que vem a ser o semantismo do substantivo apoia-se na análise de como ocorre o desenrolar do processo enunciativo que o compreende (ver métodos, infra). O centro de nossas atenções é, não o término do processo de significação (o sentido adquirido), mas o processo em si (o que está em seu fundamento).

A esse respeito, pode-se dizer que o semantismo se traduz por "princípios regulares de se estabelecerem relações com os elementos do cotexto" (FRANCKEL, 2011a, p. 25), por princípios ditos invariantes. Conforme Culioli, dos fenômenos empíricos, por mais que sejam singulares e variados, “(...) emerge uma atividade autorregulada de pôr em relação e de interação, que organiza e estrutura entidades heterogêneas. Isso engendra uma proliferação de possíveis, mas desses possíveis emergem invariantes" (2002, p. 27, tradução nossa).

$\mathrm{Na}$ base do conceito de invariância, tem-se uma atividade autorregulada de pôr em relação, uma atividade constituída de relações regulares que, de um lado, mobilizam parâmetros variáveis, de outro "se mantêm estáveis sob diferentes transformações" (ROMERO, 2019, p. 183) ${ }^{10}$.

Para o que nos interessa neste trabalho, o conceito de semantismo tal como exposto é suficiente. $\mathrm{O}$ estudo analítico trará os aportes necessários a seu aprofundamento. Importa-nos, na seção a seguir, apresentar a síntese das análises resultantes dos trabalhos mencionados a fim de tratar, tanto do caráter único da dinâmica enunciativa específica a CHAVE e FACA por

\footnotetext{
${ }^{8}$ Sobre o funcionamento semântico-enunciativo de QUEBRAR, ver Romero (2019) e seção 2, neste artigo.

${ }^{9} \mathrm{O}$ autor emprega o termo cotexto para referir ao agenciamento da unidade linguística no enunciado, a seu contexto verbal. Guardamos o termo nas citações, mas, em outras passagens do artigo, utilizamos contexto.

${ }^{10}$ Conforme explicamos em Romero (2019), o conceito de invariância remete ao que é, intrinsecamente, estável e deformável, dotado de plasticidade. Tal conceito decorre do posicionamento teórico para o qual não existe uma relação biunívoca entre o nível cognitivo, igualmente denominado por Culioli nível nocional, e o nível linguístico, no qual se verifica a produção verbal. Em outras palavras, não há "correspondência termo a termo entre, de um lado, marcadores em uma dada língua e, de outro, categorias (...) que encontraríamos através das línguas" (CULIOLI, 1990, p. 15, tradução nossa). Como nota Culioli, a dificuldade reside neste ponto; mas onde reside a dificuldade, reside o que consideramos o mais belo achado da teoria, posto que é a não adequação entre o nível cognitivo (nível nocional) e o nível linguístico que faz com que se verifiquem fenômenos que são, simultaneamente, estáveis e plásticos, dotados de uma estabilidade deformável, que abarca a variação, o ajustamento intersubjetivo: “(...) há sempre, no sentido mais forte, construção interpretativa dos fenômenos de superfície pelos enunciadores; há sempre proliferação da linguagem a partir de si mesma; temos sempre um jogo de formas e um jogo de significações. A comunicação se dá nesse ajustamento mais ou menos bem sucedido, mais ou menos desejado (...). Assim, compreende-se melhor porque um texto não tem sentido fora da atividade significante dos enunciadores, e porque a ambiguidade (e o mal entendido) são não apenas explicáveis, mas ainda parte integrante do modelo (...)" (CULIOLI, 1999a, p. 48, tradução nossa).
} 
meio da caracterização de seu semantismo, quanto das regularidades que perpassam essas dinâmicas no que concerne os modos como se elabora a variação semântica.

Com relação a este último propósito, buscamos, ademais, refletir sobre as semelhanças entre tais regularidades e as que sustentam a variação semântica de unidades verbais. Isso acrescenta um objetivo suplementar ao artigo, que é mostrar que o modo de variação do substantivo e do verbo responde aos mesmos princípios, o que valida a existência de princípios invariantes de ordem mais geral, que abarca ambas as classes.

\section{Processo de significação do substantivo: métodos e resultados preliminares}

Pelo que é de nosso conhecimento, não há trabalhos sobre o funcionamento semântico-enunciativo de substantivos em português do Brasil no âmbito do modelo de identidade lexical proposto pela TOE. Os resultados apresentados podem ser vistos como balizadores para pesquisas futuras.

No modelo mencionado, a invariância à qual faz referência o semantismo do substantivo é representada pelo conceito de forma esquemática (note-se FE) (FRANCKEL, 2002, DE VOGÜÉ et al., 2011, ROMERO, 2019).

A FE constitui a base de um trabalho de abstração que permite investigar e formalizar o papel do substantivo (no SN) e do contexto (desse mesmo SN) na variação dos sentidos que, comumente, são associados apenas ao elemento focalizado na análise. Cabe à FE descrever o conjunto dos empregos do substantivo que caracteriza, sem assimilar a descrição a um ou outro sentido em específico. Nas palavras de Franckel, a FE "não é o sentido da palavra, a identidade que constitui não é uma substância autônoma, não é o menor denominador semântico comum dos empregos de uma palavra" (FRANCKEL, 2011a, p. 26). Para o autor, o conceito evidencia que "a unidade se inscreve num duplo processo interativo de esquematização (ou configuração) do cotexto, por um lado, e de instanciação desse esquema pelos elementos desse cotexto, por outro" (FRANCKEL, 2011a, p. 25). Em suma, a forma esquemática corresponde a uma forma abstrata invariante que exprime o modo de integração do substantivo (no $\mathrm{SN}$ ) ao enunciado.

Sobre o procedimento metodológico empregado, apoiamo-nos na elaboração de glosas, uma prática de reformulação concebida por Culioli como explicação de texto (CULIOLI; NORMAND, 2005, p. 106). Nas análises, a glosa adquire um estatuto particular ao se instituir como um procedimento que supõe necessariamente um trabalho de abstração, fundamentado no vai-e-vem entre o empírico e o formal: "ao permitir escapar à evidência 
ofuscante da compreensão imediata, [a glosa] visa a estabelecer uma desintricação do papel desempenhado na construção do sentido desse enunciado pelas unidades que o constituem" (FRANCKEL, 2011b, p. 121). O que se pretende é recuperar um saber não consciente relacionado aos empregos que fazemos do substantivo. Isso implica, em primeiro lugar, que se examine sob qual ótica os termos com os quais o substantivo se enuncia o apreendem.

Tomando como ilustração empregos de CHAVE, diríamos que o SN a chave da seleção brasileira pode referir a um jogador específico, como se verifica no enunciado "Por muitos anos, o Pelé foi a chave da seleção brasileira" (FERREIRA, 2009) ${ }^{11}$. Nesse enunciado, CHAVE constrói uma representação na qual se atribui a Pelé (pelo jogo que apresentava, por sua capacidade de raciocínio ou por uma qualidade outra) uma função primordial nos campeonatos. Pelé é quem permitia à seleção ter um jogo diferenciado, avançar na disputa, ganhar títulos, etc., é quem conduzia a seleção a uma situação que tinha grandes chances de se mostrar mais bem avaliada do que a existente.

Esse mesmo SN pode aparecer, contudo, em enunciados nos quais CHAVE elabora a representação de uma configuração constituída por equipes esportivas (na qual se inclui a seleção ${ }^{12}$ ) que travam disputas entre si, no interior da própria configuração. Nesse caso, estar na chave, ou fazer parte de uma dada configuração, é condição sine qua non para se avançar no campeonato. CHAVE, nesses empregos, gerencia o acesso a uma situação positivamente qualificada, posto que, mais se avança, mais perto do título se está.

Há, certamente, outras contextualizações desse SN. Mas aquelas trazidas e suas respectivas reformulações (glosas) permitem compreender a natureza da análise: atentamos para as representações construídas por CHAVE em cada um de seus empregos, de modo a reconstituir regularidades passíveis de explicarem um conjunto de enunciados distintos. No caso, as contextualizações apontam para uma característica importante do funcionamento semântico-enunciativo desse substantivo: o fato de CHAVE gerenciar o acesso de uma situação à outra, melhor avaliada ou positivamente qualificada.

A reformulação dos enunciados subsidia a investigação sobre o que há de invariante e sistemático no processo de significação, evidenciando regularidades enunciativas próprias ao substantivo para confrontá-las a novos enunciados.

As subseções a seguir têm por fundamento os resultados obtidos por Fujisaka (2020) e Francisconi (2020). Embora o substantivo se apresente sob uma multiplicidade de construções

\footnotetext{
${ }^{11}$ Os enunciados aqui apresentados ou constam de fontes lexicográficas (FERREIRA, 1999; HOUAISS, VILLAR, 2009), ou foram coletados na web. Sobre constituição do corpus, ver infra, nessa mesma seção.

${ }^{12}$ Ver "O Brasil estreia na competição na sexta-feira, contra a Espanha, pelo Grupo D. México e Japão completam a chave da seleção brasileira". Disponível em: https://bityli.com/A66zt. Acesso em: 16 fev. 2021.
}

195 - Conexão Letras, Porto Alegre, v. 16, n. 25, p. 191-220, jan-jun. 2021. 
que lhe conferem valores semânticos distintos, interessa-nos formalizar o seu semantismo para, a partir dessa formalização, explicar como a variação semântica se elabora por meio de princípios regulares de variação.

Sobre o levantamento dos enunciados nos quais CHAVE e FACA se fazem presentes, considerou-se, inicialmente, o verbete em fontes lexicográficas (FERREIRA, 1999, HOUAISS, VILLAR, 2009). Após verificar o que estas fontes traziam como exemplos, realizou-se uma vasta pesquisa na WEB, variando-se a distribuição do substantivo ao integrar um sintagma (por ex., para CHAVE, a chave, uma chave, a chave da, chave na, na chave, chave de, chave para, etc.) a fim de coletar contextualizações outras, não necessariamente presentes nas fontes lexicográficas. A coleta resultou em um total de, aproximadamente, 200 (duzentos) enunciados para CHAVE e 90 (noventa) para FACA, enunciados em que há variação de construções e de valores semânticos, sendo que, desses, 25 (vinte e cinco) considerados representativos do emprego de CHAVE são analisados por Fujisaka (2020) e 34 (trinta e quatro), de $\mathrm{FACA}^{13}$, por Francisconi (2020).

A seguir, analisamos separadamente cada substantivo para, ao término, fazer as nossas considerações sobre os princípios que incidem na variação.

\subsection{Variação e invariância de CHAVE}

Para o estudo da variação própria a CHAVE, selecionamos os enunciados abaixo, representativos de seu funcionamento semântico-enunciativo. A análise focaliza o $\mathrm{SN}$ e a representação por ele construída em sua integração ao enunciado. Partimos da análise dos enunciados em sua singularidade e sem uma ordem específica de apresentação, verificando quais são as regularidades que perpassam o conjunto.

1. Assim que meteu a chave na fechadura, ouviu um barulho estranho e não-identificado vindo de dentro do apartamento. ${ }^{14}$

\footnotetext{
${ }^{13}$ Notemos que a diferença no número de enunciados coletados não condiz necessariamente com a diferença de construções ou valores semânticos observados. Assim, consta da tabela de dados de CHAVE inúmeros enunciados nos quais aparecem o SN a chave para, como em "Agroenergia é a chave para um desenvolvimento sustentável" (Disponível em: https://bityli.com/8SZ5d, acesso em: 16 fev. 2021). Nesses enunciados, elabora-se um valor no qual CHAVE se aproxima de uma condição a ser verificada para que se tenha uma outra situação. Houve, portanto, a coleta de vários exemplos para ilustrar um mesmo funcionamento enunciativo. Nos estudos de Fujisaka (2020) e Francisconi (2020), por sua vez, os exemplos analisados são aqueles nos quais os substantivos tendem a adquirir valores semânticos distintos ou a integrar uma construção diferenciada. A esse respeito, não deixa de ser interessante notar a grande variedade de construções tidas por "idiomáticas" integradas por FACA, caso, por ex., de "com a faca na(o)" (Ver VILELA, FRANCISCONI, 2020): "Se ele for forçado com a faca na garganta, acaba tomando uma decisão fraca, que não é duradoura, nem racional" (Disponível em: https://bityli.com/PXKbX, acesso em: 16 fev. 2021).

${ }^{14}$ Disponível em: https://bityli.com/bPhyv, acesso em: 16 fev. 2021. Ver ainda tabela de dados anexa ao trabalho de Fujisaka (2020), cujos dados integram o banco Léxico e Enunciação, sob responsabilidade de Romero.
}

196 - Conexão Letras, Porto Alegre, v. 16, n. 25, p. 191-220, jan-jun. 2021.

E-ISSN 2594-8962. DOI: https://doi.org/10.22456/2594-8962.116838 
O SN a chave (na fechadura) constrói uma representação na qual CHAVE se refere ao próprio objeto de abertura/fechamento de um dispositivo (a fechadura de uma porta). Na cena enunciativa construída, o objeto gerencia a possibilidade de acesso a um outro estado de porta (destrancada), distinto do anterior, e que consiste no estado almejado (libera-se a entrada).

2. Se a pessoa perceber durante o banho que a temperatura não está adequada, nunca mude a chave com o chuveiro ligado. ${ }^{15}$

O SN a chave constrói a representação de um dispositivo regulador da corrente elétrica que o atravessa. A mudança da chave refere-se a este dispositivo que, embutido na estrutura do chuveiro, gerencia, por meio de uma gradação, o acesso da corrente responsável por aquecer a temperatura da água a fim de torná-la adequada ao banho, conforme necessidade ou vontade do sujeito.

3. Agroenergia é a chave para um desenvolvimento sustentável. ${ }^{16}$

O SN a chave para elabora, de um lado, a representação de uma situação esperada, aquela que, possibilitada pela agroenergia, é capaz de trazer um desenvolvimento sustentável, de outro, uma situação primeira, caracterizada, por um desenvolvimento não sustentável, por ex.. Ao remeter a agroenergia, i.e., à utilização, à produção de agroenergia, CHAVE em a chave para, a concebe como fator passível de gerenciar o acesso a uma situação desejável, apropriada (desenvolvimento sustentável), instaurando esta mesma situação como distinta da que se tem inicialmente.

4. A chave não está em vilanizar um ingrediente ou outro, mas, sim, apostar numa alimentação variada, com a participação de boas fontes de carboidratos e gorduras. ${ }^{17}$

O enunciado consta de uma matéria que discute estratégias para a eliminação de gordura no fígado. Assim, tem-se a presença de gordura no fígado como situação inicial ou primeira à qual se refere o SN a chave, o que pode ser explicitado por A chave [para eliminar a gordura no fígado]. Logo, o alcance de uma situação desejável, a saber a ausência de

\footnotetext{
${ }^{15}$ Disponível em: https://bityli.com/suAcH, acesso em: 16 fev. 2021.

${ }^{16}$ Disponível em: https://bityli.com/8SZ5d, acesso em: 16 fev. 2021.

${ }^{17}$ Disponível em: https://bityli.com/HZAG3, acesso em: 16 fev. 2021. 
gordura no figado, é entrevisto pelo que o SN a chave dá a ver: apostar numa alimentação variada, que gerencia a possibilidade de acesso à referida situação.

5. Nunca sentimos tanto medo - e, pior, nunca tivemos tanto medo dessa sensação. Talvez a chave do problema, e sua grande solução, morem justamente aí. Perder o medo do medo. ${ }^{18}$

O SN a chave do problema remete à reação esperada para se solucionar um problema: perder o medo do medo. Há uma situação à qual se refere o problema - a não aceitação do medo - que pode deixar de se verificar a partir de uma reação (perder o medo do medo) ao estado primeiro instituído. CHAVE, ao se referir à reação esperada, a concebe como o que gerencia um modo de se acessar outra situação ou estado.

6. As 48 seleções serão divididas em 16 grupos de três times. Os dois melhores de cada chave avançam ao mata-mata. Os 32 então viram 16, que se enfrentam em oitavas de final $(. ..){ }^{19}$

O termo CHAVE, em cada chave, mobiliza a representação de equipes que disputam entre si no interior de uma configuração, a definida pela chave (chave $A, B$, etc.). Os melhores de cada configuração seguem para a fase posterior, até se chegar ao confronto que levará apenas uma equipe à vitória. $\mathrm{O}$ seu emprego aproxima-se daquele de um suporte por meio do qual se registra uma informação: a que se refere às equipes entre as quais ocorrem os jogos de um campeonato e que, no decorrer dele, são passíveis de avançar em direção ao embate final, em busca do título. CHAVE, nesse enunciado, gerencia o acesso a uma situação positivamente qualificada, a mais próxima do título.

7. Há uma outra chave de leitura sobre os protestos verde-amarelos: para o jornalista Alon Feuerwerker, os protestos mostraram que há uma disputa dentro do bloco que elegeu Bolsonaro. ${ }^{20}$

Há explicações (não especificadas no enunciado) que buscam esclarecer o porquê dos protestos verde-amarelos. O SN uma outra chave de leitura sustenta a possibilidade de mais uma maneira de se apreender o ocorrido, relacionada à existência de uma disputa dentro do bloco que elegeu Bolsonaro (Q). Nota-se que chave de leitura registra uma informação (a existência de Q), sendo esta o elemento que gerencia uma nova apreensão do fato apresentado: o fato deve ser lido considerando-se o que Q leva a examinar.

\footnotetext{
${ }^{18}$ Disponível em: https://bityli.com/1TzjG, acesso em: 16 fev. 2021.

${ }^{19}$ Disponível em: https://bityli.com/ZAnS5, acesso em: 16 fev. 2021.

${ }^{20}$ Disponível em: https://bityli.com/DpucD, acesso em: 17 fev. 2021.. 
8. Sony processa e pede prisão preventiva para os hackers que quebraram chave do $\mathrm{PS}^{21}$

Nesse enunciado, CHAVE remete à informação, em forma de código, que controla o sistema do PlayStation 3, conhecido videogame e central de multimídia. Assim, temos que o SN chave do PS3, entendido como símbolos ordenados secretos que permitem acessar o sistema PS3, faz referência, em quebraram chave do PS3, à sua decodificação pelos hackers, ao fato de as regras de sua ordenação ou combinação terem sido violadas.

As análises apontam para algumas características essenciais do semantismo de CHAVE: trata-se de um termo que tem por papel gerenciar a possibilidade de acesso a uma situação ou estado, sendo estes almejados, desejáveis, apropriados (entre outras possibilidades que podem ser empregadas para qualificá-los positivamente) a partir de uma situação ou estado por ele definido(a) como inicial. Dadas essas características, propomos, para a caracterização de CHAVE, a seguinte formalização:

CHAVE gerencia a POSSIBILIDADE DE ACESSO a (Y), situação ou estado entrevistos positivamente, a partir de $(X)$, situação ou estado inicial.

O referido semantismo, apresentado em termos de forma esquemática ${ }^{22}$, expõe as figuras relativas aos modos de variação semântica a depender de como se constrói a POSSIBILIDADE DE ACESSO que CHAVE gerencia. Dessa construção, resultam os grupos I, II e III, cujas particularidades evidenciam a natureza da regularidade observada.

No grupo I, a POSSIBILIDADE DE ACESSO a uma situação (Y) gerenciada por CHAVE convoca uma estrutura, materializada, nos enunciados (1) e (2), pelos termos a fechadura e o chuveiro. A característica principal desse grupo é que a POSSIBILIDADE DE ACESSO é constitutiva da representação de uma estrutura que contém o dispositivo permitindo aceder a (Y). Desse modo, CHAVE leva os termos a fechadura ou o chuveiro a serem apreendidos como estrutura contendo posições (trancada/destrancada; ligada/desligada) que lhes cabe gerenciar e que possibilitam o acesso a uma situação ou estado almejados (porta trancada e/ou destrancada, temperatura adequada da água).

No grupo II, CHAVE tende a recuperar uma condição que gerencia o acesso a uma situação ou estado posterior (Y). Neste caso, a POSSIBILIDADE DE ACESSO é circunstancial, posto que dependente de um elemento ou fator externo, sem o qual não se

\footnotetext{
${ }^{21}$ Disponível em: https://bityli.com/CONzs, acesso em: 17 fev. 2021.

${ }^{22}$ Esta FE, embora fundamentada em Fujisaka (2020), reorganiza os termos de sua formalização.

199 - Conexão Letras, Porto Alegre, v. 16, n. 25, p. 191-220, jan-jun. 2021.

E-ISSN 2594-8962. DOI: https://doi.org/10.22456/2594-8962.116838
} 
acede a (Y). Enquadram-se neste segundo grupo os enunciados (3), (4) e (5). Por ex., em (3) Agroenergia é a chave para um desenvolvimento sustentável, CHAVE, em a chave para, faz referência à agroenergia (produção de, investimento em agroenergia) como condição para aceder a uma situação (Y), a representada por um desenvolvimento sustentável. A situação (Y) é distinta da situação $(\mathrm{X})$, primeira ou atual, na qual o desenvolvimento não se verifica ou é de outra ordem. CHAVE convoca agroenergia como fator externo gerenciador da possibilidade de acesso a (Y). No enunciado (4), A chave [está em] apostar numa alimentação variada (...), o fator externo tido como condição para ter acesso a (Y) é apostar numa alimentação variada (...), (Y), situação almejada, referindo-se à eliminação de gordura no fígado; já em (5), (...) Talvez a chave do problema, e sua grande solução, morem justamente aí. Perder o medo do medo., o fator externo que exprime a condição para se ter acesso à "solução do problema" é perder o medo do medo.

Por fim, no grupo III, a POSSIBILIDADE DE ACESSO ocorre por meio de CHAVE fazendo as vezes de um suporte, i.e. registrando informação que se elabora exclusivamente por meio dela. Este grupo abarca os enunciados (6), (7) e (8), em que CHAVE faz referência à informação por meio da qual se dá, respectivamente, em (6), a configuração (de equipes esportivas) que permite avançar a (Y), i.e. seguir no campeonato, em (7), o conhecimento (do fato, de um assunto) que permite avançar a (Y), i.e. ter uma leitura diferenciada do texto e, em (8), o conhecimento da ordenação de símbolos constitutiva de um código que permite ter acesso ao que ele codifica.

Se retomarmos cada grupo em uma relação ainda mais estreita com a forma esquemática, vemos o porquê desta se apresentar como um semantismo de natureza relacional constituída por parâmetros variáveis, conforme explicado anteriormente. Vemos, ainda, os princípios que regem o modo como esses parâmetros se enunciam.

No grupo I, CHAVE responde por seus próprios parâmetros de funcionamento ao convocar, no enunciado, termos que podem ser apreendidos como uma estrutura dotada, em si, do que gerencia a POSSIBILIDADE DE ACESSO à situação (estado) (Y). É o caso dos enunciados (1) e (2), nos quais CHAVE remete ao que integra um dispositivo no qual se verificam posições (trancada/destrancada, ligada/desligada) que gerenciam o acesso a (Y). No grupo II, CHAVE convoca um elemento externo, de natureza circunstancial e tido por um fator condicionante (uma condição), como gerenciador da POSSIBILIDADE DE ACESSO a (Y). No grupo III, constata-se que não há gerenciamento da POSSIBILIDADE DE ACESSO interno, como em I, em que se representa um dispositivo constitutivo de uma estrutura, nem 
externo (circunstancial), como em II, em que se representa um fator condicionante. Neste caso, CHAVE é, ao mesmo tempo, o que gerencia A POSSIBILIDADE DE ACESSO e o que dá a ver (Y): os parâmetros são indissociáveis.

Dada a natureza complexa do raciocínio - o que, vale ressaltar, é próprio ao grupo III, como veremos adiante -, exemplificamos com os enunciados (6) e (8). Em (6), CHAVE faz referência a uma configuração de equipes esportivas. Aqui, CHAVE gerencia a POSSIBILIDADE DE ACESSO a uma situação (Y) - apresenta-se uma configuração de equipes - ao mesmo tempo em que dá a ver as equipes que avançam no campeonato e que nele permanecem. Ou seja, o acesso a uma situação $(\mathrm{Y})$ - o avanço no campeonato - é indissociável da presença das equipes na CHAVE, na configuração. Em (8), CHAVE faz referência a uma ordenação de símbolos constitutiva de um código. Neste exemplo, CHAVE gerencia o acesso a uma situação (Y) - o codificado, por ex., um sistema de dados - que não existe enquanto codificado fora da CHAVE em si.

\subsection{Variação e invariância de FACA}

Notemos que se CHAVE tende a elaborar valores qualificados positivamente em muitos de seus empregos, o que se explica por um semantismo que remete à POSSIBILIDADE DE ACESSO a (Y), situação almejada, desejável, FACA, por remeter à descontinuidade de algo cuja tendência seria a de se perpetuar ou se conservar, pende, embora não em todos os empregos, para valores qualificados negativamente: é a faca que corta, põe fim, intimida. Há, em FACA, pelo fato de se ter como ponto de partida um querer se perpetuar ou se conservar, ou então, o que pode vir a resistir à sua própria interrupção ou extinção, contextos impregnados, muitas vezes, de violência, moral ou física: contextos de ameaça, imposição, usurpação, intimidação, para ficar apenas nesses.

Nas análises que seguem, selecionamos alguns de seus usos. Partimos daqueles considerados prototípicos e exploramos outros empregos, considerando-se os mesmos procedimentos analíticos já mencionados.

1. Depois de muitas decepções, finalmente comprei uma faca que me deixou satisfeito. $^{23}$

A primeira definição do verbete FACA no dicionário Houaiss e Villar (2009) é a de um "instrumento constituído por lâmina cortante presa a um cabo", definição tida por

\footnotetext{
${ }^{23}$ Disponível em: https://bityli.com/jjB7e, acesso em: 18 fev. 2021. Ver ainda tabela de dados anexa ao trabalho de Francisconi (2020), cujos dados integram o banco Léxico e Enunciação já mencionado.

201 - Conexão Letras, Porto Alegre, v. 16, n. 25, p. 191-220, jan-jun. 2021.

E-ISSN 2594-8962. DOI: https://doi.org/10.22456/2594-8962.116838
} 
prototípica. O instrumento é ainda considerado como próprio para cortar, retalhar, separar, fatiar, etc. No enunciado, elabora-se uma representação na qual o termo FACA, no SN uma faca que me deixou satisfeito, é justamente apreendido como um instrumento constituído de um fio (especificado pela lâmina cortante) de qualidade. Na representação construída, o fio é caracterizador da própria faca.

2. O cadáver reanimado pelas sementes de Treena estava furioso, ele passou a faca com força no pescoço da bruxa, fazendo-a gritar de dor. ${ }^{24}$

O SN a faca é, aqui, argumento de passar. Nesse exemplo, apreende-se o termo $o$ pescoço como a superfície linear da pele. Passou a faca no pescoço faz referência à separação que incide sobre o tecido da pele por meio do corte da faca, ou melhor, sobre o tecido entendido como um só órgão (um contínuo) revestindo o corpo humano.

3. A Netflix não gosta de perder dinheiro e passa a faca mesmo em séries com um bom número de defensores (não espectadores). ${ }^{25}$

Passar a faca aparece num contexto no qual um conjunto de produções são canceladas. São produções realizadas de modo seriado, o que significa que o capítulo ou a temporada seguinte vincula-se ao (à) anterior. Passar a faca refere-se não à retirada das séries do catálogo, mas ao cessar da continuidade de sua produção: A FACA, no SN a faca exprime o corte que interrompe uma sequência (de episódios) inclinada a perdurar.

4. Como você pode falar em cortar isso e aquilo e não cortar o Sistema S? Tem que meter a faca no Sistema $\mathrm{S}$ também. Vocês estão achando que a CUT perde o sindicato e aqui fica tudo igual... Acho que tem que cortar pouco para não doer muito. $^{26}$

O enunciado pode ser assim reformulado: em um programa de cortes orçamentários generalizado, o Sistema $\mathrm{S}^{27}$ não poderia ficar de fora. Cortar isso e aquilo e não cortar o

\footnotetext{
${ }^{24}$ Disponível em: https://bityli.com/foqCz, acesso em: 18 fev. 2021.

${ }^{25}$ Disponível em: https://bityli.com/AG3Qj, acesso em: 18 fev. 2021.

${ }^{26}$ Disponível em: https://bityli.com/oZe7p, acesso em: 18 fev. 2021.

27 Sobre o Sistema S, ver https://bityli.com/F6r03, acesso em: 18 fev. 2021: "O sistema S é composto por uma série de instituições e representa um conjunto de organizações e entidades voltadas para questões profissionais diversas. De uma forma geral, elas servem de apoio para a indústria, para o varejo e para os próprios trabalhadores, em diferentes ramos. O sistema é mantido mediante a contribuição compulsória das empresas, com alíquotas variadas. Em geral, as taxas variam de 0,2 a 2,5\%, dependendo do tipo de negócio e do regime de tributação escolhido. A alíquota incide sobre a folha de pagamento e, por isso, empreendimentos maiores pagam mais".
} 
Sistema $S$ constrói uma representação na qual se concebe o referido sistema a princípio como intocável, de modo que meter na faca exprime a sua entrada na agenda de cortes. Pelo fato de existir regularidade no fluxo de caixa ou constância de aportes garantida, existe também resistência à menção de corte. $\mathrm{O}$ corte, em si, representa uma redução imposta à garantia de aportes, o que acarreta a diminuição de fluxo. Esse encadeamento de ideias é importante porque, se qualquer momento de perda de capital é um acontecimento indesejado, isso não implica que haja algo imposto ou coação: é o sintagma meter na faca que promove essa representação.

5. Se ele for forçado com a faca na garganta, acaba tomando uma decisão fraca, que não é duradoura nem racional. ${ }^{28}$

FACA integra o sintagma preposicional (SP) com a faca na garganta, que, no enunciado, elabora uma representação na qual o sujeito pode se ver forçado a tomar uma decisão contra a sua vontade, o que não lhe deixaria espaço para manobras. Interessante observar que se apreende a garganta como o que permite a passagem do que é passível de ser interrompido pelo corte da faca, podendo ser este o próprio fluxo de ar que sai e entra dos pulmões ou de sangue que corre pelas veias. Em suma, a faca na garganta refere-se à dominação sobre a situação: qualquer resistência por parte do sujeito em relação ao que lhe é imposto não tem como prevalecer se a imposição de fato ocorrer. O termo FACA representa o movimento de interrupção de algo que poderia tomar um dado curso e sobre o qual se projeta, finalmente, uma orientação não qualquer.

6. CANSEI DE SER A BOAZINHA Agora to com a faca na calcinha. ${ }^{29}$

A contraposição entre o emprego de cansar no pretérito perfeito e o que se tem agora, no momento da enunciação, estabelece uma relação entre ser boazinha e estar com a faca na calcinha, mas não sob a ótica do ser boa ou má, e sim, sob aquela de ter uma atitude passiva ou ativa. Essa propensão à atitude de se lançar, de se impor, se faz presente de modo potencial: está lá, pronta a se manifestar. A faca na calcinha tende a se referir ao empoderamento feminino, à tomada de atitude passível de pôr um fim a qualquer comportamento alheio que não seja não condizente com os pontos de vista assumidos.

\footnotetext{
${ }^{28}$ Disponível em: https://bityli.com/ueBlI, acesso em: 18 fev. 2021.

${ }^{29}$ Disponível em: https://bityli.com/wp4Rk, acesso em: 18 fev. 2021. Mantivemos as opções gráficas na transcrição. 
7. Um Mercúrio em Áries é direto e impulsivo, não suporta enrolações, é aquele que muitas vezes tem uma faca na língua, fala o que vem à cabeça. ${ }^{30}$

Ter a faca na língua é ser alguém que não mede as palavras. Como bem mostra o enunciado, é ser alguém que fala o que vem à cabeça, o termo a língua referindo-se ao próprio ato de fala, ao que pode ser proferido. A expressão aponta, ainda, para a possibilidade de um ataque verbal iminente à fala de outrem. A troca verbal é constantemente ameaçada pelo ataque que pode vir a encerrá-la. Uma vez mais, elabora-se a representação de uma tomada de atitude, dessa vez, verbal e de tom contundente, passível de pôr fim à fala de outrem.

8. Se você jogar Lillian Witte Fibe no Google, vai encontrar o nome da jornalista ligado a expressões como "peitar", "criticar" e "trocar farpas". O gaúcho diria: ela é faca na bota. $(\ldots)^{31}$

Um sujeito faca na bota aproxima-se de sujeito intrépido, destemido. A expressão faz referência àquele que traz uma faca escondida na bota ou mesmo em seu solado. Representa-se, aqui, uma propriedade de quem está em posição de ataque e não se coloca na defensiva, não volta atrás, e isso por trazer consigo o que lhe permite, justamente, partir para cima e pôr fim a qualquer situação em curso.

As análises conduzem a um esquema operatório fundamentado no princípio de que FACA se relaciona a corte. Vale notar que, enquanto as definições que lhe são dadas apoiam-se no fato de FACA ser um instrumento de corte, o que confere ao termo uma caracterização não relacional e pautada na representação do referente assim denominado, o semantismo abaixo descrito apoia-se no corte como um traço constitutivo de sua função linguística.

Corte convoca, por sua vez, a noção do que se apresenta como contínuo, linear, como fluxo $^{32}$, sendo este o parâmetro que, na formalização do semantismo de FACA, aparece como UM CONTÍNUO (Y) sobre o qual incide uma separação. Em outras palavras, FACA, termo relacionado a corte, convoca em seu funcionamento o que se vê dotado de continuidade, linearidade, fluxo, de um lado, e o fio capaz de separar, desunir, mais precisamente, descontinuar o UM CONTÍNUO, de outro.

\footnotetext{
${ }^{30}$ Disponível em: https://bityli.com/jnCKE, acesso em: 18 fev. 2021.

${ }^{31}$ Disponível em: https://bityli.com/GBgdg, acesso em: 18 fev. 2021.

${ }^{32}$ Ver Garcia (2014). 
FACA é o que permite descontinuar o que é contínuo, linear, o que se mostra como fluxo. Não é por menos que em seus empregos recupera-se de variadas maneiras $a$ continuidade, seja a da superfície, a do fluxo, a do discurso, etc. Se, contudo, a tendência do que é contínuo é a de se perpetuar, FACA impõe a descontinuidade, elaborando representações relacionadas a um aniquilamento de resistências.

Baseados no exposto, propomos, para FACA, a seguinte formalização:

FACA impõe uma DESCONTINUIDADE sobre o UM CONTÍNUO $(X)$, estado predisposto a ser resguardado.

É importante notar que o UM CONTÍNUO (X) predisposto a ser resguardado remete às propriedades evidenciadas pelos diferentes enunciados, em que $(\mathrm{X})$ se apresenta como o que tende a ser conservado, protegido, defendido - e que assim permaneceria se não fosse o fato de ocorrer algo que se impõe à continuidade de (X), que ataca $(\mathrm{X})$, o elimina, anula, o faz cessar, ser interrompido, etc.

As análises mostram ainda a existência de figuras relativas aos modos de variação semântica, a depender da natureza da DESCONTINUIDADE que se impõe ao UM CONTÍNUO. Resultam dessa relação os grupos I, II e III.

No grupo I, temos enunciados como (1) e (2), uma vez que, neles, FACA elabora a representação de um instrumento cortante cujo fio capaz de descontinuar o UM CONTÍNUO é caracterizador da própria faca. E isso, vale dizer, independentemente de FACA remeter, nos enunciados, a contextualizações em que está ou não em uso. Nesse grupo, o UM CONTÍNUO (X) se vê determinado como um corpo sólido.

Assim, em (2) (...) ele passou a faca com força no pescoço da bruxa (...), FACA se impõe sobre o pescoço, apreendido como UM CONTÍNUO (X), i.e. sob a ótica da continuidade de um mesmo órgão (a pele), tecido que reveste o corpo humano. Sem essa imposição, observa-se uma tendência à conservação da integridade do pescoço. Um outro exemplo para esse uso, entre tantos outros, é Ele chegou a ferir os policiais. Cortou com a faca o colete de um deles ${ }^{33}$, em que colete é apreendido como UM CONTÍNUO (X), uma extensão de fibras entremeadas passível de sofrer corte.

\footnotetext{
${ }^{33}$ Disponível em: https://bityli.com/5rVSf, acesso em: 22 fev. 2021.

205 - Conexão Letras, Porto Alegre, v. 16, n. 25, p. 191-220, jan-jun. 2021.

E-ISSN 2594-8962. DOI: https://doi.org/10.22456/2594-8962.116838
} 
Salientamos que toda a gama de designadores faz parte desse grupo, tais como faca de peixe, de pesca, de arrasto, de caça etc. No grupo I, constrói-se, portanto, uma representação de corte intrínseco à $\mathrm{FACA}^{34}$, posto que relacionado ao fio que a constitui.

Já no grupo II, o UM CONTÍNUO, elaborado circunstancialmente, faz referência ao que se situa no espaço-tempo. Há uma ampla variedade de exemplos que pertencem a esse grupo, como ilustram os enunciados (3), (4) e (5).

Em (3), A Netflix (...) passa a faca mesmo em séries com um bom número de defensores, o UM CONTÍNUO (X) remete a uma sequência de séries ou episódios de uma série produzida em um determinado período. É sobre essa continuidade de produção que FACA incide, exprimindo o corte que interrompe uma sequência (de episódios) inclinada a perdurar. Em (4), (...) Tem que meter a faca no Sistema $S$ também. (...), FACA incide sobre (X), o fluxo orçamentário destinado ao Sistema $\mathrm{S}$ em um dado período, descontinuando este fluxo: impõem-se restrições a um aporte cuja tendência seria a de se perpetuar. Por fim, em (5) Se ele for forçado com a faca na garganta, acaba tomando uma decisão fraca, a expressão a faca na garganta representa a possibilidade de interromper (X), o fluxo (de ar, de sangue), e imobilizar o sujeito: qualquer descontinuidade nesse fluxo impede o respiro para uma tomada de decisão assertiva.

Enquanto no grupo I o corte pode resultar em divisão ou separação de (X) (de uma superfície, por ex.), no grupo II, o movimento de corte constrói representações de ameaça, supressão, restrição que conduzem a uma interrupção, a ser ou não efetivada. Neste grupo, evidencia-se a ideia de poder: são confrontadas disposições distintas e FACA possibilita a quem a detém o fato de se impor sobre o outro, sobre o UM CONTÍNUO (X).

No grupo III, FACA representa um corte (uma descontinuidade) sem o qual não seria possível fazer menção à existência do UM CONTÍNUO $(\mathrm{X})$. Verifica-se que, se não há corte sem $(\mathrm{X}),(\mathrm{X})$ só vem ao caso porque se postula um corte que já está dado, haja o que houver. Os enunciados (6), (7) e (8) são exemplos desse corte latente: há uma propensão do sujeito a se impor, um modo de ser e agir que se faz presente de modo potencial, que está lá, apenas no

\footnotetext{
${ }^{34}$ É preciso dizer que, embora FACA possa elaborar representações variáveis relacionadas à própria manipulação do objeto, se se faz uso da ponta da faca para perfurar ou de sua lâmina para cortar, em relação ao esquema operatório, não há mudanças, visto que se trata de uma continuidade a ser descontinuada por algo que a ela se impõe. Em "Victor usou a ponta da faca e raspou o musgo seco que estava travando a pedra e após isto empurrou com a maior força que pode" (Disponível em: https://bityli.com/hyXqJ, acesso em: 22 fev. 2021), o SP a ponta da faca, evoca a representação de musgo seco enquanto um entremeado contínuo: raspar, rasgar, cortar, em suma, o movimento necessário para romper essa estrutura ou se isso é simples ou complexo, se exige ou não força, advém do fato de que FACA evoca, nos seus parâmetros, o que é contínuo. Um outro exemplo, "Chega de dar murro em ponta de faca" (Disponível em: http://bit.ly/3aMhUlr, acesso em: 24 fev. 2021), o SP em destaque constrói a representação de uma situação atual sem saída porque recupera um estado anterior em que havia saída, ou seja, recupera o que fluía (contínuo).
} 
aguardo para se manifestar. Neste grupo, parte-se dessa qualidade do sujeito para recuperar aquilo sobre o qual incide a imposição.

Em (6) CANSEI DE SER A BOAZINHA Agora to com a faca na calcinha, FACA refere-se à tomada de atitude (relacionada, por ex., ao empoderamento feminino) que repele o UM CONTÍNUO $(\mathrm{X})$, apreendido como modos de pensar ou agir comumente observados que devem ser repelidos. O corte ao qual se faz referência é aquele que não mais valida uma situação. Em (7) Um Mercúrio em Áries (...) é aquele que muitas vezes tem uma faca na língua, fala o que vem à cabeça, FACA elabora a representação de uma tomada de atitude por parte de um sujeito, dessa vez, verbal e de tom contundente, que se impõe e deslegitima a fala de outrem. Em (8) (...) O gaúcho diria: ela é faca na bota, faca na bota diz sobre o modo de ser de alguém que apresenta uma conduta inflexível, propensa a atacar e não a se colocar na defensiva. Refere-se a um caráter intrépido, capaz de descontinuar (parar, destruir) qualquer UM CONTÍNUO que se lhe apresente.

\subsection{Princípios relacionados aos modos de variação}

Os substantivos CHAVE e FACA, apesar de originarem um conjunto de ocorrências que, tradicionalmente, poderíamos classificar de concreto, originam também mais dois grupos de ocorrências em que essa classificação não se encaixa. Falar de polissemia ou uso metafórico, a nosso ver, mais tangencia a questão do que a resolve.

O que as nossas análises mostram é que lidamos com unidades que se configuram, sim, de acordo com os agenciamentos dos enunciados nos quais são inseridas, mas, sobretudo, que esses agenciamentos - ou seus contextos de inserção - respondem a invariâncias de funcionamento, àquelas às quais se referem CHAVE e FACA em suas formas esquemáticas e às exemplificadas pelos grupos I, II e III. No posicionamento aqui adotado, não falamos, assim, de um emprego de base, o considerado prototípico, do qual derivariam outros empregos por extensão metafórica.

Como inicialmente dito, as configurações observadas, independentemente de sua natureza, resultam de um mesmo funcionamento operatório, descrito pela forma esquemática do substantivo. Essa forma reconfigura-se a cada emprego, conforme os usos respondem aos parâmetros de variação. Contudo, há também princípios de variação que a regulam e que dão origem aos grupos, o que mostra que os respondentes, nos usos, se ordenam a partir deles. 
Para compreendê-los, é necessário abordar, ainda que sumariamente ${ }^{35}$, alguns conceitos fundamentais constitutivos deste quadro.

Em primeiro lugar, importa notar que a representação nocional ou, simplesmente, a noção à qual essas unidades linguísticas remetem não é apreensível a não ser através das suas ocorrências, que, ao mesmo tempo em que fazem referência à noção, são realizações singulares que dela se elaboram nos enunciados. São realizações singulares porque pertencem ao nível linguístico (nível II), em que se constroem enunciados que, à sua maneira, pelas relações únicas ali estabelecidas, reformulam as operações próprias ao trabalho linguageiro inerente ao nível nocional (nível I, também dito cognitivo) ${ }^{36}$. O que constitui o nível nocional ou cognitivo (nível I) toma corpo no enunciado sob agenciamentos não quaisquer, de modo que, para se chegar à invariância característica do nível I, é preciso examinar as diferentes relações constitutivas desses agenciamentos - elas mesmas traços da invariância em questão e quais regularidades são possíveis de, nelas, serem entrevistas.

Cada ocorrência de CHAVE e FACA remete, conceitualmente falando, a $<$ ser P $>$, respectivamente, a $<$ ser $\mathrm{CHAV}>$ e a $<$ ser $\mathrm{FAC}>$, o símbolo $<$ ser $\mathrm{P}>$ referindo-se à noção $P$, "objeto de cunho qualitativo topologicamente concebido como um domínio de propriedades, a ser notado pela sigla QLT” (ROMERO, 2019, p. 210). A tais propriedades, propõe-se uma formalização em termos de relações regulares, de invariantes que ordenam o modo como a unidade se enuncia.

Por outro lado, se a noção é dependente de um enunciado que a configure e que lhe dê acesso, isso não significa que ela venha a se resumir, como dissemos, à configuração por meio da qual ela se manifesta (ou se instancia), i.e às suas ocorrências. Em suma, falar:

(...) em noção é falar desse domínio de propriedades; já falar em ocorrência da noção, é apreender a noção instanciada em um enunciado, é situá-la espaçotemporalmente. A ocorrência, ao conferir uma delimitação à noção por instanciá-la, é caracterizada pela sigla QNT. (ROMERO, 2019, p. 211)

\footnotetext{
${ }^{35}$ Para aprofundamento, ver Culioli (1990, 1999a, 1999b). Ver ainda Romero (2018a, 2019).

${ }^{36}$ A esse respeito, podemos mencionar a observação que Culioli faz sobre "interior-exterior" ou "atividade de linguagem-língua": "Mas quando é um interior que passa por uma exteriorização, não é exatamente o mesmo interior que aquele que é verdadeiramente a nossa atividade interna. O problema da língua, é justamente esse" (CULIOLI, NORMAND, 2005, p. 109). Vê-se, por essa colocação, que ao produzirmos e/ou compreendermos enunciados, acessamos a nossa atividade interna, a atividade linguageira própria ao nível I, sem que a atividade de produção e/ou compreensão ocorrida no nível II abarque a atividade interna que, simultaneamente, se dá. A palavra de ordem é, portanto, a não-coincidência entre os níveis I e II.
} 
No quadro referencial da TOE, o enunciado é, portanto, uma forma empírica que comporta os traços de operações inacessíveis, características do referido trabalho linguageiro. No enunciado, verifica-se:

\begin{abstract}
(...) a construção de "algo", situado no espaço-tempo por um enunciador (...), isto é um "quantum” (daí a designação metalinguística QNT), que é uma "ocorrência de", onde de indica que não existe ocorrência que não seja ocorrência de uma noção. Assim, toda ocorrência é qualificada nocionalmente. (...) O símbolo metalinguístico da operação de Qualificação é QLT. (CULIOLI, 1999b, p. 62, grifos do autor, tradução nossa)
\end{abstract}

QNT e QLT são conceitos operacionais de fundamento. QNT diz respeito ao espaço enunciativo que, ao instanciar a noção, lhe atribui determinações específicas, mais precisamente, ao fato de se conferir uma espessura espaçotemporal a uma propriedade cuja realidade não é sensível ${ }^{37}$. QLT, ao qualitativo, ao material nocional ao qual se tem acesso e que se apresenta como um domínio de propriedades.

As configurações relativas aos grupos I, II e III elaboram-se a partir de articulações entre o qualitativo das noções e o "quantum" das ocorrências. Para explicá-las, apoiamo-nos no que denominamos forma (relação) interna e forma (relação) externa, que especificam os modos como os elementos do enunciado respondem aos parâmetros da FE.

Retomemos, para tanto, as FE de CHAVE e FACA:

(a) CHAVE gerencia a POSSIBILIDADE DE ACESSO a (Y), situação (estado) entrevista(o) positivamente, a partir de (X), situação (estado) inicial;

(b) FACA impõe uma DESCONTINUIDADE sobre o UM CONTÍNUO (X), estado predisposto a ser resguardado.

No que se refere à forma (relação) interna, própria ao grupo I, os elementos que respondem aos parâmetros da FE se apresentam sob uma configuração na qual um é constitutivo do outro.

No caso de CHAVE, a POSSIBILIDADE DE ACESSO (parâmetro 1) é constitutiva da representação de dispositivo (de uma estrutura) permitindo aceder a (Y) (parâmetro 2). São exemplos a chave da fechadura ou a chave do chuveiro. CHAVE convoca termos (fechadura,

\footnotetext{
${ }^{37}$ Ver Romero e Flores (2017), em que se apresenta uma análise conceitual do emprego de incorporal em Culioli, entre outras importantes reflexões teóricas a ele relacionadas. Sustentam-se, por meio dessas reflexões, os conceitos operacionais QNT e QLT ora descritos. Como explicam os autores, "O incorporal remete a dois pontos essenciais: ao jogo de relações - a uma teoria da abstração - e aos modos de existência sobre os quais se fundam as representações linguísticas (e os gestos, profissionais, manuais, para falar apenas desses), um que está ocultado, outro que é percebido, o que nos faz compreender que 'é a partir de algo de material, constituído de relações sem materialidade, que construímos objetos perceptíveis, sensoriais, portanto acessíveis' (CULIOLI; NORMAND, 2005, p. 41). Esse algo de material, constituído de relações sem materialidade, 'tende para, há um elã' (CULIOLI; NORMAND, 2005, p. 260), o telos sendo 'a atividade interna orientada, construtiva e regulada' 'a capacidade de ter pro-jetos', de buscar 'o que convém' (CULIOLI; NORMAND, 2005, p. 261-264, grifos de Culioli) para fazer o que é preciso fazer.” (ROMERO, FLORES, 2017, p. 124, tradução nossa)
} 
chuveiro) que, ao responderem aos parâmetros, os inserem numa relação de inerência: a representação de um dispositivo que faz com que se aceda a (Y) se apoia, de modo inerente, no que gerencia a POSSIBILIDADE DE ACESSO. Podemos dizer que a POSSIBILIDADE DE ACESSO (parâmetro 1) é PARTE do dispositivo. Nos enunciados desse grupo, falar em CHAVE é remeter a um dispositivo do qual ela é parte. Já no caso de FACA, a DESCONTINUIDADE (parâmetro 1) passível de se impor sobre o UM CONTÍNUO (parâmetro 2) é constitutiva da representação de um instrumento cortante. Ou seja, elabora-se, no enunciado, a representação de um instrumento cujo fio capaz de descontinuar o UM CONTÍNUO é caracterizador do próprio instrumento. Observa-se, igualmente, uma relação PARTE-TODO pelo fato de $o$ fio ser constitutivo do instrumento (TODO).

Nesse grupo, põe-se em jogo uma relação em que se verifica uma espécie de medida interna à noção permitindo que se ateste (valide) um estado resultante: com CHAVE, a POSSIBILIDADE DE ACESSO, constitutiva da representação de dispositivo, permite mesurar (atestar, validar) a existência de uma mudança de estado: trancada/destrancada, por ex; com FACA, a DESCONTINUIDADE trazida por um fio capaz de descontinuar permite mesurar (atestar, validar) a existência de uma mudança de estado: pele (do pescoço) com corte/sem corte.

No que se refere à forma (relação) externa, própria ao grupo II, o que responde aos parâmetros da FE se apresenta sob uma configuração marcada pela circunstancialidade, pelo situacional, posto que relacionada a um dado espaço-tempo. Ao se enunciarem, CHAVE e FACA apoiam-se em outros termos para responder aos seus parâmetros de funcionamento.

No caso de CHAVE, a POSSIBILIDADE DE ACESSO (parâmetro 1) é circunstancial, i.e. dependente de um elemento ou fator externo, sem o qual não se acede a (Y) (parâmetro 2), ele mesmo de natureza situacional. O enunciado Agroenergia é a chave para um desenvolvimento sustentável é um exemplo: nele, CHAVE apreende agroenergia como fator externo (condição) que gerencia a POSSIBILIDADE DE ACESSO à situação (Y) (um desenvolvimento sustentável). Por sua vez, nos enunciados de FACA, a DESCONTINUIDADE (parâmetro 1) e o UM CONTÍNUO (parâmetro 2) são de natureza circunstancial: a descontinuidade faz referência ao corte que se opera num dado instante e o UM CONTÍNUO, ao que assim se concebe em relação ao espaço-tempo. Em A Netflix (...) passa a faca mesmo em séries com um bom número de defensores, o UM CONTÍNUO (X) remete a uma sequência (de séries ou episódios de uma série) produzida em um determinado 
período (espaço-tempo), FACA exprimindo o corte que cessa algo (uma sequência) inclinado a perdurar.

Na relação em que há o circunstancial, CHAVE aponta para mudança de situação, enquanto FACA, para interrupção, para o movimento que cessa algo cuja tendência seria a de perdurar - ou ao menos permanecer na situação em que se encontra.

O grupo III põe em jogo uma configuração na qual não se mobilizam, nem uma forma (relação) interna, nem externa. Observa-se, ao contrário, a atribuição da propriedade formalizada pela forma esquemática por meio de um suporte, o que leva esse suporte a existir apenas em função da referida propriedade. Trata-se de um raciocínio complexo, por implicar uma relação de indissociabilidade (autoengendramento) entre parâmetros, o que é melhor entendido pela retomada dos exemplos.

No caso de CHAVE, ilustrado por As 48 seleções serão divididas em 16 grupos de três times. Os dois melhores de cada chave avançam ao mata-mata. (...), CHAVE consiste em um suporte para registrar uma informação, a que exprime uma configuração de equipes esportivas. A POSSIBILIDADE DE ACESSO (parâmetro 1) é indicada pelo registro da informação, sendo que a informação lida indica igualmente os que têm possibilidade de avançar a uma nova situação (Y) (ou os que já avançaram). Em suma, o avanço no campeonato é indissociável da presença das equipes na configuração. CHAVE registra uma configuração que engendra novas configurações, o avanço de uma configuração à outra correspondendo ao avanço no campeonato ${ }^{38}$.

No caso de FACA, ilustrado por CANSEI DE SER A BOAZINHA Agora to com a faca na calcinha, FACA representa um corte (uma DESCONTINUIDADE imposta) sem o qual não seria possível fazer menção à existência do UM CONTÍNUO (X). Verifica-se uma relação de autoengendramento, já que, se não há corte sem $(\mathrm{X}),(\mathrm{X})$ só vem ao caso porque se postula um corte que, haja o que houver, está dado. Nesse enunciado, o suporte da propriedade à qual se refere FACA é o sujeito. Atribui-se a ele a propriedade de descontinuar (parar, destruir) qualquer (X) que se lhe apresente (X podendo ser lido como modos de pensar ou agir comumente observados que devem ser repelidos).

\footnotetext{
${ }^{38}$ Isso permite reformular os SP chave da fechadura, chave do problema e chave do campeonato a partir dos princípios que sustentam cada grupo. Em chave da fechadura, grupo I, CHAVE apreende a fechadura como dispositivo, do qual é parte constitutiva. Em chave do problema, grupo II, CHAVE apreende o problema com algo a ser gerenciado por ela (fator externo). E em chave do campeonato, grupo III, CHAVE apreende $o$ campeonato como jogos que, ao mesmo tempo, a configuram e são gerenciados por ela (por essa mesma configuração). Esses SP tendem a se apresentar sob a ótica de funcionamento dos grupos mencionados, sem que isso signifique que esses funcionamentos são exclusivos. Nada impede que chave do campeonato tenha seu funcionamento relacionado ao grupo II ou mesmo I, porém seriam desencadeados agenciamentos não quaisquer nos enunciados capazes de sustentá-los.
} 
Sobre as articulações entre QNT e QLT nas quais se fundamentam os princípios regulando cada grupo, devemos considerar, portanto, que:

- QLT refere-se à noção, logo, à propriedade invariante (formalizada pela forma esquemática) ${ }^{39}$;

- QNT refere-se à noção $<$ ser $\mathrm{P}>$ instanciada no enunciado, às suas ocorrências.

Em relação aos grupos I, II e III e às articulações entre QNT e QLT nas quais se fundamentam os princípios reguladores de cada grupo, pode-se dizer que:

- tem-se QNT-QLT quando a noção (QLT), ou a referida propriedade invariante, se funda numa forma (relação) interna orientando a sua instanciação, i.e. a construção de ocorrências (QNT);

- tem-se QNT quando a noção (QLT), ou a referida propriedade invariante, se funda numa forma (relação) externa, circunstancial, que decorre da própria instanciação, i.e. da construção de ocorrências (QNT);

- tem-se QLT quando a noção (QLT) não mobiliza uma forma (relação) interna ou externa e, sim, a atribuição de propriedade (QLT) a um suporte no enunciado.

Como afirmamos no início desta seção, trata-se de uma exposição sumária de conceitos de grande complexidade, mas que responde ao objetivo do trabalho, o de evidenciar regularidades por meio das quais se dá a variação dos substantivos analisados.

Nosso propósito, a seguir, é o de confrontar tais resultados com os que obtivemos em etapas anteriores da pesquisa direcionada a unidades verbais.

\section{Processo de significação do verbo: algumas considerações}

Partimos, em relação ao verbo, não de seus enunciados, como fizemos com os substantivos, mas da formalização de seu semantismo, para, por meio dela, examinar os grupos em que se observam os modos de variação verbal.

O verbo QUEBRAR é a unidade precursora dessa pesquisa e, de sua investigação, resultaram trabalhos que abordam, para além dos princípios invariantes que sustentam o processo de significação (ROMERO, 2018a; ROMERO, 2019), fenômenos outros relacionados, por ex., à alternância ergativa em PB (ROMERO, no prelo). É a ele que vamos nos ater como ilustração, remetendo a esses trabalhos em complemento ao que será aqui exposto.

\footnotetext{
${ }^{39}$ Por ex., a propriedade $<$ ser $\mathrm{P}>$, em CHAVE, é $<$ ser CHAV $>$, logo, gerenciar a possibilidade de acesso a $Y$. 212 - Conexão Letras, Porto Alegre, v. 16, n. 25, p. 191-220, jan-jun. 2021. 
QUEBRAR é uma unidade que exprime, para o senso comum, algo sólido que perde a sua integridade. Não é por menos que se vê associado a um valor semântico como despedaçar. No entanto, em sua forma esquemática, há um invariante que evidencia "o que se encontra em uma relação estreita de dependência recíproca ou causalidade com o outro, por nós denominada solidaridade ${ }^{40}$ " (ROMERO, 2019, p. 205).

Notamos, aqui, a mudança na concepção do semantismo, já que postular uma SOLIDARIDADE como propriedade de QUEBRAR, é lhe propor uma identidade de natureza relacional, que se manifesta em referência à existência de constituintes interdependentes. Logo, QUEBRAR institui uma SOLIDARIDADE ao se enunciar, a ser lida como interdependência entre constituintes, para representá-la como desfeita.

Por exemplo, com o SN o carro, QUEBRAR, em Quebrou o carro, vai apreendê-lo ora como mecanismo, qualquer que seja o mecanismo em questão (mecânico, elétrico), ou como a estrutura ou mecanismo de um brinquedo (um carrinho de controle remoto seria uma possibilidade). A apreensão como mecanismo remete a constituintes interdependentes (SOLIDARIDADE), a elementos cujas funções, dependentes umas das outras, concorrem para o funcionamento (mecânico, elétrico) do conjunto; como estrutura, a constituintes interdependentes (SOLIDARIDADE), a partes dispostas umas em relação às outras na composição do todo.

Já com o SN a rotina, QUEBRAR, em Quebrou a rotina, vai apreendê-lo como atividade que se atualiza em um dado instante e que se refere, simultaneamente, a um instante anterior em que se observa uma atualização dessa mesma atividade. Os constituintes interdependentes (SOLIDARIDADE) se manifestam como prática sistemática de algo, em que a própria sistematicidade indica a presença de uma ordenação.

Um último exemplo é o caso do SN a palavra, em Quebrou a palavra. QUEBRAR o leva a ser apreendido como um vínculo entre sujeitos (SOLIDARIDADE) por meio de uma declaração verbal de compromisso.

Vê-se, portanto, que QUEBRAR confere uma determinação específica a esses termos, fazendo com que sejam lidos pela propriedade de SOLIDARIDADE que ele lhes confere para, finalmente, expressar a SOLIDARIDADE desfeita: o mecanismo que deixa de funcionar ou a estrutura que perde a sua integridade, a prática sistemática que cessa ou se interrompe, o compromisso instituído verbalmente que perde a sua validade ${ }^{41}$.

\footnotetext{
${ }^{40}$ Em nota, é dito que a forma pouco usual do termo foi escolhida para expressar a referida propriedade.

${ }^{41}$ Os termos convocados pelo verbo QUEBRAR, tal como o verbo, não apresentam a priori um valor de base, por mais que, às vezes, tenhamos essa impressão. Não se trata de postular sentidos prévios à construção na qual os termos se inserem. Por ex., palavra, em outros enunciados, em nada lembra uma declaração verbal, como se 213 - Conexão Letras, Porto Alegre, v. 16, n. 25, p. 191-220, jan-jun. 2021. 
Não deixa de ser impressionante verificar, nas análises, um agrupamento de termos que respondem muito nitidamente aos princípios regulares que sustentam o modo pelo qual a SOLIDARIDADE se instancia nos enunciados.

No grupo I, evidencia-se uma SOLIDARIDADE interna: a SOLIDARIDADE (X) atualiza-se como um TODO intrinsecamente formado de PARTES, de constituintes interdependentes (Y). QUEBRAR tem por núcleo do SN salto, página, dedo, carro, relógio, empresa, sistema, código, etc., um amplo conjunto de termos passíveis de serem apreendidos sob a ótica de uma estrutura, um mecanismo, um sistema, um organismo, etc. Quebrar o salto representa a quebra do salto (parte) do sapato (todo), sapato sendo apreendido como estrutura (poderia ser também salto como a própria estrutura); Quebrar a página, página (parte) em relação a texto (todo); Quebrar o dedo, dedo (parte) em relação a mão, pé (todo), ou então dedo como estrutura óssea ( $o$ dedo é o todo do qual decorrem partes). Nos outros exemplos, em Quebrar o relógio, o carro, um mecanismo, como já discutido; em Quebrar o sistema, o código, um conjunto ordenado e fechado de elementos e/ou relações, em Quebrar a empresa, tem-se empresa como estrutura econômica, como sistema consolidado de atividades (produção, distribuição, troca e consumo de bens, por ex.) que resulta, com a quebra, em uma estrutura (econômica) destruída. Nesse grupo I, a quebra resulta em uma destruição de ordem interna que se manifesta de várias maneiras: há destruição estrutural, o que enguiça, se arruína, etc.

No grupo II, evidencia-se uma SOLIDARIDADE externa: a SOLIDARIDADE (X) atualiza-se como o que é dotado de sistematicidade espaçotemporal. Os constituintes são de natureza circunstancial, dado que é no espaço-tempo que se elabora a relação de interdependência. Observa-se, assim, um fenômeno ordenado em relação aos instantes em que se atualizam e sem os quais a regularidade não existiria: fenômenos que se reiteram ou periódicos, práticas sistemáticas, elementos sequenciais, etc., tais como $A$ onda quebrou, Quebrou a rotina, Quebrou o ritmo, e ainda a tradição, o costume, o fio da conversa, a direção, etc. Examinando esses termos quando enunciados com QUEBRAR, notamos que onda remete à representação de um movimento ondulatório dotado de regularidade, ritmo, à representação de uma repetição periódica ordenada de intervalos (por ex., em uma composição musical); rotina, a uma repetição de hábitos, prática constante; tradição,

observa em Escreva uma palavra qualquer, desde que seja afetuosa. Há uma estreita integração, na construção da significação, entre o termo que o verbo convoca para se enunciar e QUEBRAR: o verbo leva o termo a manifestar propriedades condizentes com o seu funcionamento e é na observação das propriedades associadas aos termos que começa a se delinear o próprio papel do verbo. A não existência de sentidos prévios à inserção do termo no enunciado se verifica, aliás, na pesquisa atual direcionada aos substantivos. 
representa o que se pratica por um costume adquirido, devido a valores transmitidos de geração a geração; costume representa igualmente uma prática frequente, um modo de agir habitual. Ao lado desses termos, encontram-se o fio da conversa, a direção, que remetem ao desenrolar de um movimento, ao encadeamento ou concatenamento de um assunto ao outro (fio da conversa) ou do rumo a ser tomado (direção), entre tantos outros termos possíveis. Entende-se, assim, a importância que o SP para esquerda adquire no enunciado Ele quebrou para esquerda, elemento que faz com que QUEBRAR possa exprimir uma mudança de direcionamento do rumo.

No grupo III, evidencia-se uma SOLIDARIDADE que se apresenta por meio de vínculos (morais, afetivos, etc.) entre os constituintes, não existindo constituintes a não ser pela SOLIDARIDADE atribuída ao que será o suporte do vínculo. Os $\mathrm{SN}$ argumentos do verbo elaboram representações que remetem a engajamentos entre partes, prescrições legais, morais, como em Quebrou a promessa, a palavra, os laços, o protocolo, o contrato, entre outros. Notamos, consequentemente, que promessa, palavra, são apreendidos como declaração verbal de compromisso dada a outrem e que institui um vínculo entre partes, sendo os sujeitos o suporte desse mesmo vínculo: não há promessa ou palavra fora daquele a quem se promete ou a quem a palavra é dada. O raciocínio é o mesmo para os outros casos: laços é apreendido como aliança ou tratado, como um vínculo unindo indivíduos, povos, sob determinadas bases; protocolo, como um conjunto de normas reguladoras a ser seguido, o protocolo não se verificando a não ser pelo seu cumprimento, pela existência de quem nele se engaja; contrato, como um acordo formal no qual pessoas e/ou entidades estabelecem cláusulas a serem cumpridas, etc.

Não nos propomos a recuperar análises que podem ser lidas nos trabalhos mencionados ${ }^{42}$. O que percebemos, pelo conjunto de termos instituídos pelo funcionamento semântico-enunciativo de QUEBRAR, é que a propriedade se manifesta, em cada grupo, a partir de princípios invariantes. Desse modo:

- no grupo I (QNT-QLT), o que é próprio à noção <ser QUEB>, i.e. a propriedade SOLIDARIDADE, convoca uma forma (relação) interna: exprime-se a SOLIDARIDADE por meio de constituintes interdependentes que lhe são inerentes (representa-se o estrutural, por ex.);

- no grupo II (QNT), o que é próprio à noção <ser QUEB>, i.e. a propriedade SOLIDARIDADE, convoca uma forma (relação) externa: exprime-se a

\footnotetext{
${ }^{42}$ Sobre questões específicas que envolvem a idiomaticidade, ver Romero (2017). 
SOLIDARIDADE por meio de constituintes interdependentes de ordem circunstancial (representa-se o reiterável, por ex.);

- no grupo III (QLT), o que é próprio à noção <ser QUEB>, i.e. a propriedade SOLIDARIDADE não convoca uma forma (relação) interna ou externa: o constituinte interdependente é indissociável da propriedade de SOLIDARIDADE atribuída a um suporte (representa-se o vínculo, por ex.).

Em conclusão, QUEBRAR elabora uma SOLIDARIDADE que se desfaz. Em termos interpretativos, os enunciados do grupo I tendem a exprimir uma destruição estrutural pelo fato de remeterem a uma dessolidarização de natureza interna; os do grupo II, a interrupção ou cessação de fenômenos ordenados, reiterados, pelo fato de remeterem a uma dessolidarização de natureza circunstancial (externa); por fim, os do grupo III tendem a exprimir uma perda de vínculo que invalida o próprio estatuto de constituinte interdependente. Não se verifica, neste último grupo, uma dessolidarização (interna ou externa) como em I ou II, e, sim, predica-se uma não solidaridade ao suporte, o que mostra uma inversão de raciocínio. Se nos grupos I e II parte-se do que apresenta a propriedade SOLIDARIDADE para construir a dessolidarização, esteja ela fundada numa relação interna ou externa, no grupo III, parte-se da NÃO SOLIDARIDADE atribuída (por ex., da quebra da palavra, que exprime não existirem vínculos entre sujeitos) para, justamente, concebê-los como partes engajadas (constituintes interdependentes) apenas no tempo em que a palavra é mantida.

\section{Considerações finais}

A Teoria das Operações Enunciativas propõe um redirecionamento no modo como se concebe o processo de construção da significação pela atividade de linguagem. Construção, sim, pois o sentido, afinal, é uma conquista, resultado de operações elementares, esquemas que os engendram, "invariantes que fundam e regram a atividade de linguagem tal como ela aparece por meio das configurações das diferentes línguas" (CULIOLI, 1999a, p. 96).

Ao se enunciarem, FACA, CHAVE, QUEBRAR são objetos linguísticos que remetem, respectivamente, à noção $<$ ser $\mathrm{FAC}>$, $<$ ser $\mathrm{CHAV}>$, $<$ ser QUEBR $>$. Somente pelos enunciados é que a noção ganha contorno, se manifesta espaçotemporalmente.

O semantismo - invariante que é - constitui-se de relações que integram parâmetros aos quais os enunciados respondem. Se os sentidos - ou valores semânticos - que a unidade 
linguística adquire em uso são inúmeros e se, sobre eles, não há controle, sabemos, no entanto, que se elaboram a partir de determinados princípios.

No que se refere ao substantivo, FACA e CHAVE, tidos como exemplos prototípicos de substantivo comum, feminino, primitivo, simples e concreto, ao se enunciarem, apresentam funcionamentos que fogem a essas classificações. O concreto, finalmente, consiste em uma ocorrência entre outras, a que se configura sob QNT-QLT, próprio ao grupo I. O caráter concreto, como qualquer outro, é visto como um resultado: por ser construído pelo enunciado, não corresponde a uma propriedade de base.

É interessante observar, contudo, a afinidade entre a configuração QNT-QLT (grupo I) e o sentido frequentemente percebido como literal ou denotativo, com a ressalva de que não estamos afirmando que qualquer enunciado pertencente a esse grupo possa ser assim categorizado. Notamos essa afinidade no conjunto das unidades verbais por nós analisadas e nos substantivos aos quais nos dedicamos até o momento. Por ora, o que se vê é que ela é uma consequência da forma (relação) interna específica à configuração QNT-QLT.

Retomando a relação noção-ocorrência:

A noção, notada QLT, apresenta-se (...) "como insecável, i.e. não fragmentada, tomada em bloco (característica do trabalho em intensão) (...). Podemos designá-la pela expressão ter a propriedade $P$ ". De outro lado, "a encarnação dessa noção sob forma de linguagem, consiste na passagem (de uma representação mental, incorporal) a uma materialidade, ao mesmo tempo que a um sistema de referenciação", o que corresponde a um "pôr em forma" da noção que notamos QNT. (ROMERO, 2018a, p. 307, cita, entre aspas, CULIOLI, 1999b, p. 10, tradução nossa)

Ora, na configuração QNT-QLT (grupo I):

(...) a ocorrência é necessariamente oriunda de uma formatagem intrínseca: (...) temos "noções pré-formatadas", o que significa que as ocorrências têm "uma decupagem prévia a toda ancoragem espaçotemporal que só faz se realizar - no tempo e no espaço - como uma verdadeira ocorrência da noção (...)" (ROMERO, 2018a, p. 307, cita, entre aspas, DE VOGÜÉ, 1989, p. 7) $)^{43}$.

Para compreender a referida citação, trazemos, aqui, uma explicação sumária, a ser exemplificada por meio das considerações feitas nesse artigo ${ }^{44}$. A forma (relação) interna remete à formatagem intrínseca acima mencionada, o que quer dizer que a noção, ao se enunciar sob o modo QNT-QLT, traz consigo o que exprime a POSSIBILIDADE DE ACESSO, para <ser CHAV>, a DESCONTINUIDADE, para <ser FAC $>$, os constituintes

\footnotetext{
${ }^{43}$ Além do artigo de De Vogüé (1989), mencionamos também De Vogüé (2014), outro importante trabalho.

${ }^{44}$ Para maiores desenvolvimentos, ver o artigo em questão.
} 
interdependentes, para $<$ ser QUEBR $>$. O enunciado nada mais faz do que atestar algo que se encontra pré-construído por ser constitutivo da noção nesse modo de funcionamento.

Como explicamos na seção 1.3., no grupo I, os elementos que respondem aos parâmetros da FE se atualizam sob uma configuração na qual um é constitutivo do outro. No caso de CHAVE, a POSSIBILIDADE DE ACESSO (parâmetro 1) é constitutiva da representação de dispositivo (de uma estrutura) permitindo aceder a (Y) (parâmetro 2). No caso de FACA, a DESCONTINUIDADE (parâmetro 1) passível de se impor sobre o UM CONTÍNUO (parâmetro 2) é constitutiva da representação de um instrumento cortante. Elabora-se, no enunciado, a representação de um instrumento cujo fio capaz de descontinuar o UM CONTÍNUO é caracterizador do instrumento. Já no caso de QUEBRAR, conforme visto na seção 2, a SOLIDARIDADE (parâmetro 1) atualiza-se como um TODO intrinsecamente formado de PARTES, de constituintes interdependentes (parâmetro 2).

Em conclusão, existem processos de estabilização do sentido cujo ponto de partida é o intrinsecamente deformável, a invariância. Esses processos não se fazem por deslocamentos ou extensões metafóricas: as configurações constitutivas dos grupos I, II e III não são concebidas como uma extensão uma da outra, nem como anteriores uma à outra. A noção, ao se instanciar no espaço enunciativo, reorganiza-se, a cada vez, segundo os princípios invariantes conceituados por relações que põem em jogo QNT e QLT.

\section{Referências}

CAMACHO, Roberto Gomes et al.. O Substantivo. In: ILARI, R. (Org.) Gramática do português culto falado no Brasil: Volume III: palavras de classe aberta. São Paulo: Contexto, 2014.

CULIOLI, Antoine. Pour une linguistique de l'énociation: opérations et représentations. Paris: Ophrys, 1990.

. À propos de la notion, In: RIVIÈRE, Claude; GROUSSIER, Marie-Line. (Dir.) La notion. Paris: Ophrys, 1997, p. 9-24.

Ophrys, 1999a.

Pour une linguistique de l'énonciation: formalisation et opérations de repérage. Paris:

Pour une linguistique de l'énonciation: domaine notionnel. Paris: Ophrys, 1999b.

À propos de même. In: FRANCKEL, Jean-Jacques. (Dir.) Le lexique, entre identité et variation. Langue Française, n. 133, Paris: Larousse, février 2002.

CULIOLI, Antoine; NORMAND, Claudine. Onze rencontres sur le langage et les langues. Paris: Ophrys. 2005.

De VOGÜÉ, Sarah. Discret, dense, compact: les enjeux énonciatifs d'une typologie lexicale, In: FRANCKEL, Jean-Jacques (Dir.). La notion de prédicat, Collection ERA 642, Paris 7, 1989, p. 1-37.

. Effets sémantiques, syntaxiques et énonciatifs du jeu entre quantité et qualité. In: CAMUS, Rémi; DE VOGÜÉ, Sarah; MÉLIS, Gérard (Dir.). Variations sémantiques et 
syntaxiques. Aspects d'une théorie de l'invariance, LinX, Nanterre: Université Paris Ouest, v. 70-71, p. 141-163, 2014.

DE VOGÜÉ, Sarah et al. Linguagem e enunciação: representação, referenciação e regulação. São Paulo: Editora Contexto, 2011.

FERREIRA, Aurélio Buarque de Holanda. Novo Aurélio Século XXI: o dicionário da língua portuguesa. 3 ed. revista e ampliada. Rio de Janeiro: Nova Fronteira, 1999.

FRANCISCONI, Leonam Ricardo Alcantara. Léxico e enunciação: a conceitualização do substantivo concreto. Questões para o ensino de línguas. Dissertação (Mestrado). Guarulhos: Universidade Federal de São Paulo, 2020. 121f.

FRANCKEL, Jean-Jacques. (Dir.) Le lexique, entre identité et variation. Langue Française, Paris: Larousse, n. 133, 2002.

. Introdução. In: DE VOGÜÉ, Sarah et al. Linguagem e enunciação: representação, referenciação e regulação. São Paulo: Contexto, 2011a, p. 15-30

. Da interpretação à glosa: por uma metodologia da reformulação. In: DE VOGÜÉ, Sarah et al. Linguagem e enunciação: representação, referenciação e regulação. São Paulo: Contexto, 2011b, p. 103-130.

FUJISAKA, Larissa Cella Hirai. Enunciação e atividade de linguagem. O substantivo comum: estudo de caso e propostas com vistas à prática de ensino. Dissertação (Mestrado). Guarulhos: Universidade Federal de São Paulo, 2020. 127f.

GARCIA, Soraia Assis. Questões de sintaxe sob a ótica enunciativa: contribuições para um ensino reflexivo da categoria verbal, Dissertação (Mestrado). Guarulhos: Universidade Federal de São Paulo, 2014, 146f.

HOUAISS, Antônio. VILLAR, Mauro de Salles. Dicionário Houaiss de Língua Portuguesa, $1^{\text {a }}$ Ed. - Rio de Janeiro: Objetiva, 2009.

ROMERO, Márcia. Léxico e enunciação: sistematização do funcionamento verbal, Relatório Científico ano II, São Paulo, FAPESP (processo 2013/07572-0), 2016.

. Cenas enunciativas ou usos idiomáticos? Identidade e variação semânticas dos verbos quebrar e comer em PB. In: V Simpósio Mundial de Estudos de Língua Portuguesa (anais), Università del Salento, 2017.

. À propos des modes de signifiance: le littéral et le figuré revus par le jeu notionnel. In: BÉDOURET-LARRABURU, Sandrine; COPY, Christine. (Org.). L'épilinguistique sous le voile littéraire. Antoine Culioli et la TO(P)E. Pau, France: PUPPA, v. 1, 2018a, p. 289-318.

Études des phénomènes morphosyntaxiques, sémantiques et discursifs liés à l'acquisition du temps verbal pretérito perfeito simples en portugais brésilien. Cahiers de Praxématique, v. 70, 2018b, p. 1-15.

. A Teoria das Operações Enunciativas In: ROMERO, Márcia; GOLDNADEL, Marcos; RIBEIRO, Pablo Nunes; FLORES, Valdir do Nascimento. Petrópolis, Rio de Janeiro: Vozes, 2019, p. 175-228.

Partiu! en portugais brésilien: contribution à l'étude de la créativité linguistique. In: RAINERI, Sophie; SEKALI, Martine; LEROUX, Agnès. (Org.) La correction en langue(s) Linguistic correction/correctness. $1^{a}$ Ed, Paris: Presses Universitaires de Paris Nanterre, v. 1, 2020, p. 177-191.

. La représentation métalinguistique de l'alternance ergative en portugais brésilien: hypothèses descriptives. In: DUFAYE, Lionel; GOURNAY, Lucie. (Org.) Métalinguistique et épilinguistique en linguistique énonciative. Paris: Presses Universitaires UPEM/UPEC (no prelo).

ROMERO, Márcia; FLORES, Valdir do Nascimento. Le linguiste et l'invention du langage. LinX, Nanterre: Université Paris Ouest, n. 74, 2017, p. 115-127. 
ROMERO, Márcia; TRAUZZOLA, Vanessa Santana Lima. Consumir et comer en portugais brésilien: contribution à l'étude du préfixe CO. Faits de Langues, Berna: Peter Lang, v. 48, 2016, p. 79-92.

ROMERO, Márcia; VILELA, Thatiana Ribeiro. Aspectos do papel enunciativo da preposição COM: objeto direto preposicionado e transitividade verbal. Revista Virtual de Estudos da Linguagem, v. 18, 2020a, p. 152-183. p. 366-399.

Preposição e prefixo em PB: uma análise transcategorial. Revista Ecos, v. 29, 2020b,

VILELA, Thatiana Ribeiro; FRANCISCONI, Leonam Ricardo Alcantara. In: $8^{\circ}$ Seminário Nacional e $2^{\circ}$ Seminário Internacional Língua e Literatura (anais). Universidade de Passo Fundo. 2020

Recebido em: 04/03/2021; Aceito em: 11/05/2021. 